\title{
Chromosomal Localization of the Human Renal Sodium Phosphate Transporter to Chromosome 5: Implications for X- Linked Hypophosphatemia
}

\author{
FAYEZ K. GHISHAN, SUSAN KNOBEL, MAJED DASUKI, MERLIN BUTLER, and JOHN \\ PHILLIPS \\ Department of Pediatrics, Divisions of Gastroenterology-Nutrition [F.K.G., S.K.] and Genetics \\ [M.D., M.B., J.P.], and the Department of Molecular Physiology and Biophysics [F.K.G.], Vanderbilt \\ University School of Medicine, Nashville, Tennessee37232-2576
}

\begin{abstract}
Hypophosphatemic vitamin D-resistant rickets, an X-linked dominant disorder, is the most common form of vitamin D-resistant rickets in humans (McKusick number 307800).

Biochemically, these patients exhibit hypophosphatemia due to a defect in the renal tubular reabsorption of phosphate. The human cDNA encoding for the renal phosphate transporter has been recently cloned using the expression system in the Xenopus laevis oocytes. Because hypophosphatemic vitamin D-resistant rickets has an X-linked mode of transmission, we hypothesized that the gene encoding the renal phosphate transporter might map to the $\mathrm{X}$ chromosome. In this report, we determined the chromosomal localization of the human renal phosphate transporter using three independent methods. First, DNA from somatic cell hybrid panels was examined by Southern blotting for the phosphate transporter. Second, the polymerase chain reaction was used to amplify DNA from somatic cell hybrids. Third, fluorescent in situ hybridization was used to sublocalize the renal phosphate transporter. All three methods localized the renal phosphate transporter to chromosome 5q13. Our results indicate that either derangement of a gene other than the phosphate transporter gene that is encoded on chromosome 5 is responsible for $\mathrm{X}$-linked hypophosphatemic rickets or, alternatively, a gene encoded on the $\mathrm{X}$ chromosome has an epistatic effect on the expression of the renal phosphate transporter on chromosome 5 .
\end{abstract}

Phosphate transport across the brush-border membranes of enterocytes and kidney proximal tubule cells occurs by a sodium-dependent process maintained by $\mathrm{Na}^{+}-\mathrm{K}^{+}$-ATPase at the baso-lateral membranes (1). This coupled sodium phosphate transport process has been described in several avian and mammalian species including man (2-4). The sodium phosphate cotransporter is influenced by the $\mathrm{pH}$ of the medium and exhibits saturation kinetics (1-6). The transporter has been expressed in Xenopus laevis oocytes $(7,8)$.

Correspondence and reprint requests: Fayez K. Ghishan, M.D., Vanderbilt University School of Medicine, Department of Pediatrics, Division of Gastroenterology/Nutrition, 21 st \& Garland Avenues, S-4322 Medical Center North, Nashville, TN 37232-2576.

Note added in proof: After the submission of our manuscript, Kos et al. presented an abstract (Am Soc Nephrol 4:72P, 1993) in which the $\mathrm{Na}^{+}$-phosphate transporter cDNA was mapped to 5q35. Although the chromosomal localization is similar to ours, the sublocalization appears different. 
Recently, the human renal sodium phosphate cotransporter has been cloned using the Xenopus oocytes expression system (9). The X-linked hypophosphatemia represents the most common form of vitamin D-resistant rickets in man (10), and it is thought that a defect in the renal $\mathrm{Na}^{+}$phosphate cotransporter might be responsible for the disorder (11). Because the disorder has as an X-linked mode of inheritance, we postulated that the renal phosphate transporter is encoded on the $\mathrm{X}$ chromosome. Our studies were designed to ascertain the chromosomal location of the human renal phosphate transporter as an initial step in determining its role in this disease.

\section{MATERIALS AND METHODS}

\section{Amplification of a genomic DNA encoding for the phosphate transporter.}

Two sets of 20 oligonucleotide primers were used to amplify the phosphate transporter gene from human genomic DNA obtained from blood. The first set included the primers (5' CTCTACCTCTTCGTCTGCTC 3') and (5' GAGTGATGT-GGTGCAGGTAG 3'). The second set included the primers (5' CACTGACCTGCAGACCTCAT 3') and (5' GGAGCAGACGAAGAGGTAGA 3'). A PCR optimizer kit (Invitrogen, San Diego, CA) was used to amplify the phosphate transporter gene with human genomic DNA used as the template. The optimal PCR reaction mixture contained $200 \mathrm{ng}$ of DNA, $0.02 \mu \mathrm{M}$ each primer, $200 \mu \mathrm{M}$ deoxynucleotides and $2.5 \mathrm{U}$ of Taq DNA polymerase in $501 / 4 \mathrm{~L}$ of $60 \mathrm{mM}$ Tris- $\mathrm{HCl}, 15 \mathrm{mM} \mathrm{NH}_{4} \mathrm{SO}_{4}$, and $2 \mathrm{mM} \mathrm{MgCl} 2$ at $\mathrm{pH} 8.5$. The reaction conditions were as follows: $96^{\circ} \mathrm{C}$ for $5 \mathrm{~min}$ followed by 31 cycles of $1.5 \mathrm{~min}$ of denaturation at $94^{\circ} \mathrm{C}$, annealing $1 \mathrm{~min}$ at $63^{\circ} \mathrm{C}$, followed by a 3 -min extension at $72^{\circ} \mathrm{C}$ with a final extension time of $10 \mathrm{~min}$ at $72^{\circ} \mathrm{C}$. PCR products were analyzed on a $1 \%$ agarose gel with ethidium bromide staining.

\section{Chromosomal localization.}

Two methods were used to determine the chromosomal assignment of the renal phosphate gene. First, somatic cell hybrid panels were probed with a 2-kb human genomic DNA fragment that was labeled using random primers with ${ }^{32} \mathrm{P}$ deoxycytidine triphosphate. DNA from somatic cell hybrid panels was subjected to digestion by Bam $H I$ restriction endonuclease (somatic cell hybrids panel catalog S4401-BamHI, Oncor Inc., Gaithersburg, MD). The blots were prehybridized for $4 \mathrm{~h}$ at $45^{\circ} \mathrm{C}$ with hybrisol I (Oncor Inc.) and hybridizations were done overnight at $45^{\circ} \mathrm{C}$. The blots were washed with $\mathrm{O} .1 \times \mathrm{SSC}(3 \mathrm{M}$ sodium chloride, $0.3 \mathrm{M}$ sodium citrate at $\mathrm{pH} 7.0$ ) and $0.1 \%$ SDS three times at room temperature and $1 \mathrm{~h}$ at $52^{\circ} \mathrm{C}$, then exposed to film under conditions recommended by the commercial supplier.

The second method was PCR amplification of somatic cell hybrid DNA using the two sets of primers used in the amplification of the phosphate transporter gene (Bios-Map somatic cell hybrid Southern DNA, Bios Labs, New Haven, CT).

FISH.

Metaphase chromosome spreads were prepared on glass microscope slides from peripheral blood lymphocyte cultures and stored in a desiccator at room temperature overnight. The slides were then treated with $1 \times$ RNase in $2 \times \mathrm{SSC}$ pH 7.0 for $1 \mathrm{~h}$ at $37^{\circ} \mathrm{C}$, dehydrated in a 
series of cold ethanol washes, and air dried. The slides were then denatured at $70^{\circ} \mathrm{C}$ for 2 min and immediately dehydrated through another series of cold ethanol washes, then air dried. The Fluorogreen (Amersham, Arlington Heights, 1L) (fluorescein-11-deoxyuridine triphosphate)-labeled probe was denatured and added to a hybridization solution containing blocking agents and $60 \%$ formamide in $2 \times \mathrm{SSC}$. The labeled probe was then placed on the metaphase spreads, covered with glass coverslips that were sealed to prevent drying, and incubated in a humidified chamber at $37^{\circ} \mathrm{C}$ for $20-24 \mathrm{~h}$. The slides were then washed through a series of $2 \times \mathrm{SSC}$ washes, counterstained with propidium iodide diluted in Antifade (Oncor Inc.), sealed with a glass coverslip, and viewed on an Olympus BH-2 fluorescent microscope. G-banding was done by incubating the metaphase spreads with trypsin [0.5 mL in $40 \mathrm{~mL}$ of Isoton (Coulter Diagnostics, Hialeah, FL)] for $30 \mathrm{~s}$, then rinsing with double-distilled water and staining with Wright's stain.

\section{Sequencing of genomic DNA.}

The PCR products were subcloned into PCR-II vector with the TA cloning kit from Invitrogen. Sequencing of PCR products was carried out by the dideoxy chain termination technique using the sequenase version 2.0 (United States Biochemical Corp., Cleveland, $\mathrm{OH})(12)$.

\section{RESULTS}

\section{Cloning of a fragment of the phosphate gene.}

Using the first set of primers, we have amplified a 600-bp fragment from genomic DNA rather than the 384-bp size expected from the cDNA sequence. Using the second set of primers, we amplified a $2-\mathrm{kb}$ fragment rather than the expected $414 \mathrm{bp}$ from the cDNA sequence, suggesting the piece we amplified from genomic DNA contained an intron. Upon sequencing the 2-kb fragment, we found $100 \%$ homology between these PCR products and the sequence of the human renal phosphate cDNA. Also, we detected donor (5' CTAGGTAGG) and acceptor (NCAGGG 3') splice site homologies and apparent intron sequences separating apparent exons of the genomic fragment.

\section{Chromosomal localization.}

Figure 1 depicts the chromosomal localization of the renal phosphate gene using the somatic cell hybrid panel. A signal is seen on chromosome 5. No signal is seen on the $\mathrm{X}$ chromosome.

Figure 2 depicts amplification of DNA from panel sets 1 and 2 of somatic cell hybrid DNA using the second set of primers, which were used to amplify the 2-kb genomic fragment. Both sets show amplifications corresponding to chromosome 5 (Bios Blot, New Haven, CT). Furthermore, we used the first set of primers to amplify a 600-bp genomic fragment. These primers also amplified somatic cell hybrid panel sets corresponding to chromosome 5 (data not shown). 


\section{Chromosomal sublocalization.}

The FISH technique was used to sublocalize the phosphate transporter gene to chromosome 5. A total of 50 cells were scored in four runs of FISH. The only consistent site for hybridization was at 5q13, which was seen in nine cells (Fig. 3). Nonspecific background hybridization did not show any locus preference. No other locus was scored more than once.

Sublocalization was supported by G-banding (data not shown) and by comparing the ratio of centromere to hybridization signal distance on chromosome $5 q$ divided by the length of chromosome 5q. An average ratio of 0.21 was calculated for our probe. This compares with the idiogram (International System for Human Cytogenetic Nomenclature, 1985) measurements of 0.19 for centromere to $5 \mathrm{ql} 3,0.11$ for centromere to $5 \mathrm{ql} 2$, and 0.29 for centromere to $5 \mathrm{q} 14$. Therefore, our average ratio of 0.21 is comparable to 0.19 calculated from the centromere to band 5q 13 in published midmetaphase chromosome idiograms (International System for Human Cytogenetic Nomenclature, 1985).

\section{DISCUSSION}

Human hypophosphatemic vitamin D-resistant rickets was described originally by Albright et al. in 1937 (13). The X-linked mode of inheritance was shown in 1958 by Winters et al. (14). Biochemically, patients have a low serum phosphate level, a high serum alkaline phosphatase level and an increased tubular excretion of phosphate. Phenotypically, patients have growth retardation and lower-limb skeletal abnormalities (10).

A hypophosphatemic mouse model (Hyp mouse) was described by Eicher et al. in 1976 (15). The Hyp mouse appears to be the animal model for the human disease because it has similar biochemical and phenotypic changes and its mode of inheritance is X-linked. The defect in the Hyp mouse and in humans with X-linked hypophosphatemia is thought to be related to an intrinsic defect in the sodium phosphate transporter $(7,11,16)$ or secondary to a circulating factor that inhibits the function of the sodium phosphate transporter (17).

Studies of human kindreds with X-linked hypophosphatemic rickets found that the human hypophosphatemic rickets locus showed $10 \%$ recombination (Lod score $=4.82)$ from the DXS41 locus that had been assigned by in situ hybridization to Xp22.1-p21.3 (18). Moreover, Machler et al. (19) found tighter linkage, $\theta=0.00$ at Lod $=5.084$, indicating that the human hypophosphatemic rickets locus is on the $\mathrm{X}$ chromosome in the region of Xp22.1-p21.3.

Because the defect in hypophosphatemic vitamin D-resistant rickets is considered to be related to decreased activity or number of renal $\mathrm{Na}^{+}$phosphate transporters $(7,11,16,17)$, we postulated that the gene for the renal phosphate transporter would be located at the $\mathrm{X}$ chromosome. Our results demonstrate that the human renal phosphate transporter does not reside on the human $\mathrm{X}$ chromosome but rather on chromosome 5 . Nonsynteny between the Hyp and human renal phosphate transporter loci is compatible with two possibilities. First, perhaps the cloned $\mathrm{Na}^{+}$phosphate transporter is not involved in the pathogenesis of hypophosphatemic vitamin D-resistant rickets and the disease is caused by defects at another phosphate transporter locus that resides on the $\mathrm{X}$ chromosome. Examples of such isoforms 
of transporters have been described recently for the $\mathrm{Na}^{+} / \mathrm{H}^{+}$exchangers $(20) . \mathrm{Na}^{+} / \mathrm{H}^{+}$ exchanger 1 (NHE-1) is localized at chromosome 1 (21), whereas NHE-3 is localized at chromosome 5 (22). Second, it is conceivable that a gene at the $\mathrm{X}$ chromosome is involved in the regulation of the phosphate transporter located on chromosome 5 and its derangement causes hypophosphatemic rickets through an epistatic effect.

Our observation should focus further investigations on human hypophosphatemic rickets.

\title{
Acknowledgments
}

Supported by NIH Grant R01 DK33209.

\author{
Abbreviations \\ PCR polymerase chain reaction \\ FISH fluorescent in situ hybridization
}

\section{REFERENCES}

1. Borowitz SM, Ghishan FK 1989 Phosphate transport in human jejunal brush border membrane vesicles. Gastroenterology 96:4-102909436

2. Borowitz SM, Ghishan FTC 1985 Maturation of jejunal phosphate transport by rat brush border membrane vesicles. Pediatr Res 19:1308-13124080450

3. Walling MW 1977 Intestinal Ca and phosphate transport: differential responses to vitamin $D_{3}$ metabolites. Am J Physiol 233:E488-E494596443

4. Danisi G, Van Os CH , Straub RW 1984 Phosphate transport across brush border and basolateral membrane vesicles of small intestine. Prog Clin Biol Res 158:229-234

5. Peterlik M , Wasserman RH 1978 Effect of vitamin D on transepíthelial phosphate transport in chick intestine. Am J Physiol 234:E379-E388645854

6. Brandis M , Harmeyer J , Jaune R , Mohrmann M , Murer H , Zimolo Z 1987 Phosphate transport in brush border membranes from control and rachitic pig kidney and small intestine. J Physiol 384:479-4902821238

7. Nakagawa N , Arab N, Ghishan FK 1991 Characterization of the defect in Na+ phosphate transporter in the vitamin D-resistant hypophosphatemic mouse. J Biol Chem 266:13616136201649826

8. Werner A , Biber J , Forgo J , Palacin M , Murer H 1990 Expression of renal transport systems for inorganic phosphate and sulfate in Xenopus laevis oocytes. J Biol Chem 265:12331-123361695629

9. Magagnin S, Wemer A, Markovich D, Sorribas V , Stange G, Biber J , Murer H 1993 Expression cloning of human and rat renal cortex Na/P, cotransport. Proc Natl Acad Sri USA 90:5979-5983

10. Rasmusseun H, Tenenhouse HS 1989 Hypophosphatemias In: Scriver CR , Beaudet AL, Sly WS , Valle D (eds) The Metabolic Basis of Inherited Disease. McGraw Hill, New York, pp 2581-2604

11. Tenenhouse HS , Scriver CR , Mclnnes RR, Glorieux FH 1978 Renal handling of phosphate in vivo and in vitro by the $\mathrm{X}$-linked hypophosphatemic male mouse: evidence for a defect in the brush border membrane. Kidney Int 11:236-244

12. Sanger F, Nicklen S , Coulson AR 1977 DNA sequencing with chain-terminat ing inhibitors. Proc Natl Acad Sci USA 74:5463-5467271968

13. Albright F, Butler AM, Bloomberg E 1937 Rickets resistant to vitamin D therapy. Am J Dis Child 54:529-534

14. Winters RW, Graham JB, Williams TF, McFalls VW, Burnett CH 1958 A genetic study of familial hypophosphatemia and vitamin D resistant rickets with a review of the literature. Medicine 37:97-14213565132 
15. Eicher EM , Southard JL, Scriver CR, Glorieux FH 1976 Hypophosphatemia: mouse model for human familial hypophosphatemic vitamin D resistant rickets. Proc Natl Acad Sci USA 73:46674671188049

16. Bell CL, Tenenhouse HS , Scriver CR 1988 Primary cultures of renal epithelial cells from Xlinked hypophosphatemic (Hyp) mice express defects in phosphate transport and vitamin D metabolism. Am J Hum Genet 43:293-3033414685

17. Nesbitt T , Coffman TM , Griffiths R , Drezner MK 1992 Crosstransplantation of kidneys in normal and Hyp mice: evidence that the Hyp mouse phenotype is unrelated to an intrinsic renal defect. J Clin Invest 89:1453-14591569185

18. Read AP, Thakker RV , Davies KE, Mountford RC, Brenton DP , Davies M, Glorieux F , Harris R , Hendy GN , King A , McGlade S, Peacock CJ , Smith R, O'Riordan JLH 1986 Mapping of human X-linked hypophosphatemic rickets by multilocus linkage analysis. Hum Genet 73:2672703015770

19. Machler M , Frey D, Gal A , Orth U, Wienker TF , Fanconi A, Schmid W 1986 X-linked dominant hypophosphatemia is closely linked to DNA markers DXS41 and DXS43 at Xp22. Hum Genet 73:271-2753015771

20. Collins JF , Honda T , Knobel S , Bulus NM , Conary J , DuBois R, Ghishan FK 1993 Molecular cloning, sequencing, tissue distribution and functional expression of a novel $\mathrm{Na}^{+} / \mathrm{H}^{+}$exchanger (NHE-2). Proc Natl Acad Sci USA 90:3938-39427683411

21. Lifton RP, Sardet C , Pouyssegur J , Lalouel JM 1990 Cloning of the human genomic amiloridesensitive $\mathrm{Na}^{+}-\mathrm{H}^{+}$antiporter gene, identification of genetic polymorphisms, and localization on the genetic map of chromosome lp. Genomics 7:131-1351970796

22. Brant SR , Bernstein M, Washmuth JJ , Taylor EW , McPherson JD , Xiang L, Walker S , Pouyssegur J , Donowitz M , Tse CM , Jabs EW 1993 Physical and genetic mapping of a human apical epithelial $\mathrm{Na}^{+} / \mathrm{H}^{+}$exchanger (NHE3) isoform to chromosome 5p 15.3. Genomics 15:6686728096830 


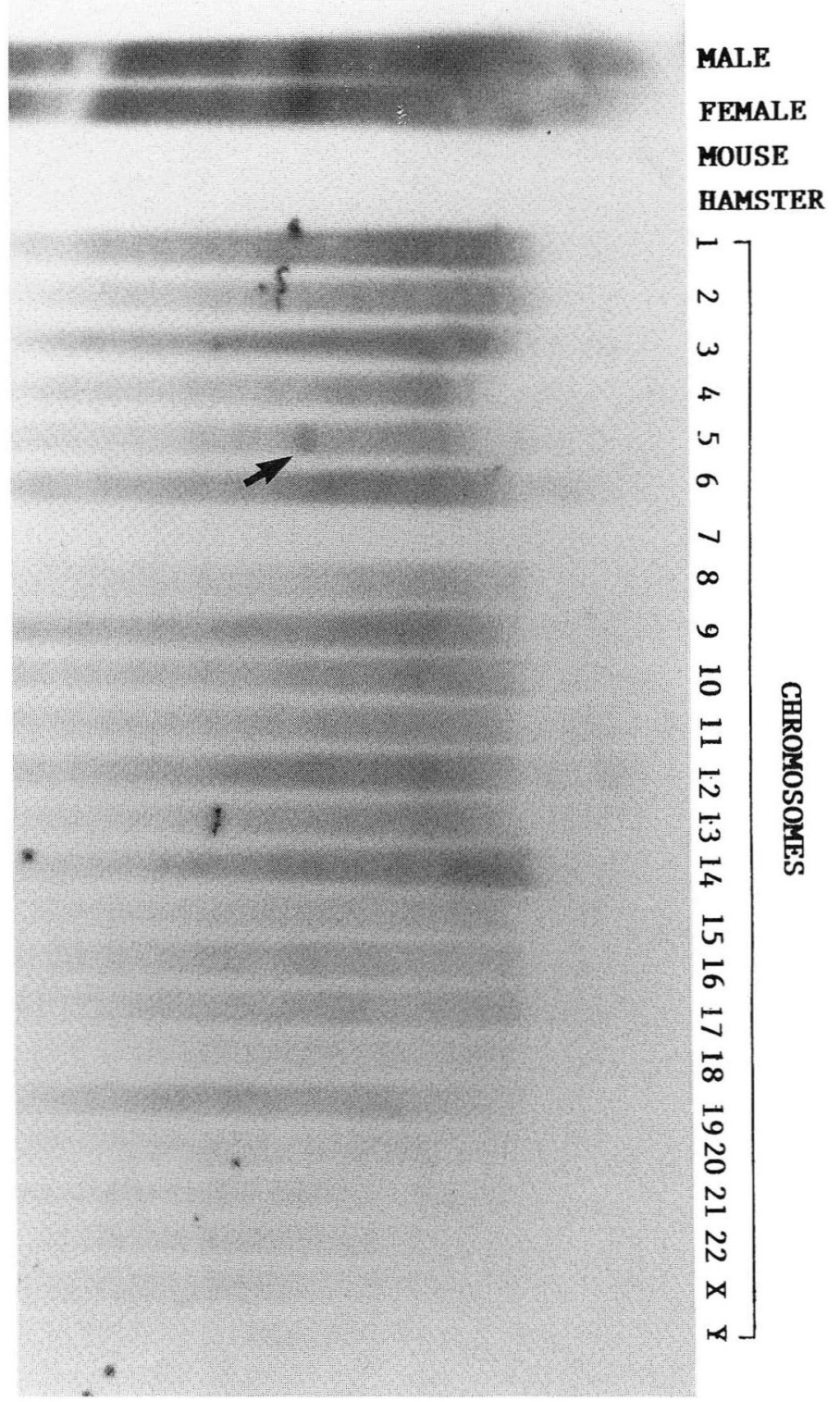

Fig. 1.

Somatic cell hybrid panel was digested with $B a m H I$ restriction enzyme and probed with a 2$\mathrm{kb}$ genomic fragment of the phosphate gene labeled with ${ }^{32} \mathrm{P}$ deoxycytidine triphosphate. A hybridization band was seen corresponding to chromosome 5 . 

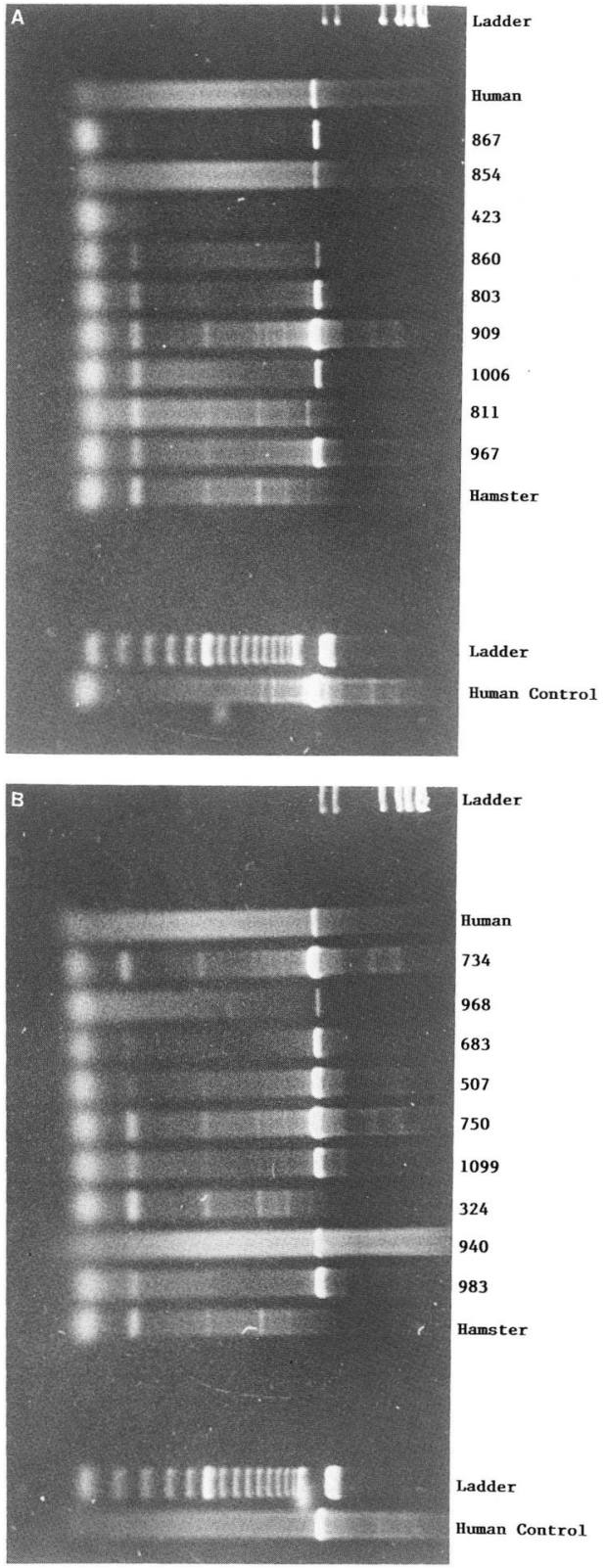

Fig. 2.

PCR amplification of somatic cell hybrids using subset I. Amplification is seen in lanes corresponding to the human control but not to the hamster. The numbers at the top of the panel are cell line designations. The bands amplified in $A$ correspond to chromosome 5. Cell lines 423 and 811 do not contain chromosome 5. Part $B$ confirms the findings in $A$, with cell line 324 showing no amplification because it does not contain chromosome 5 . 


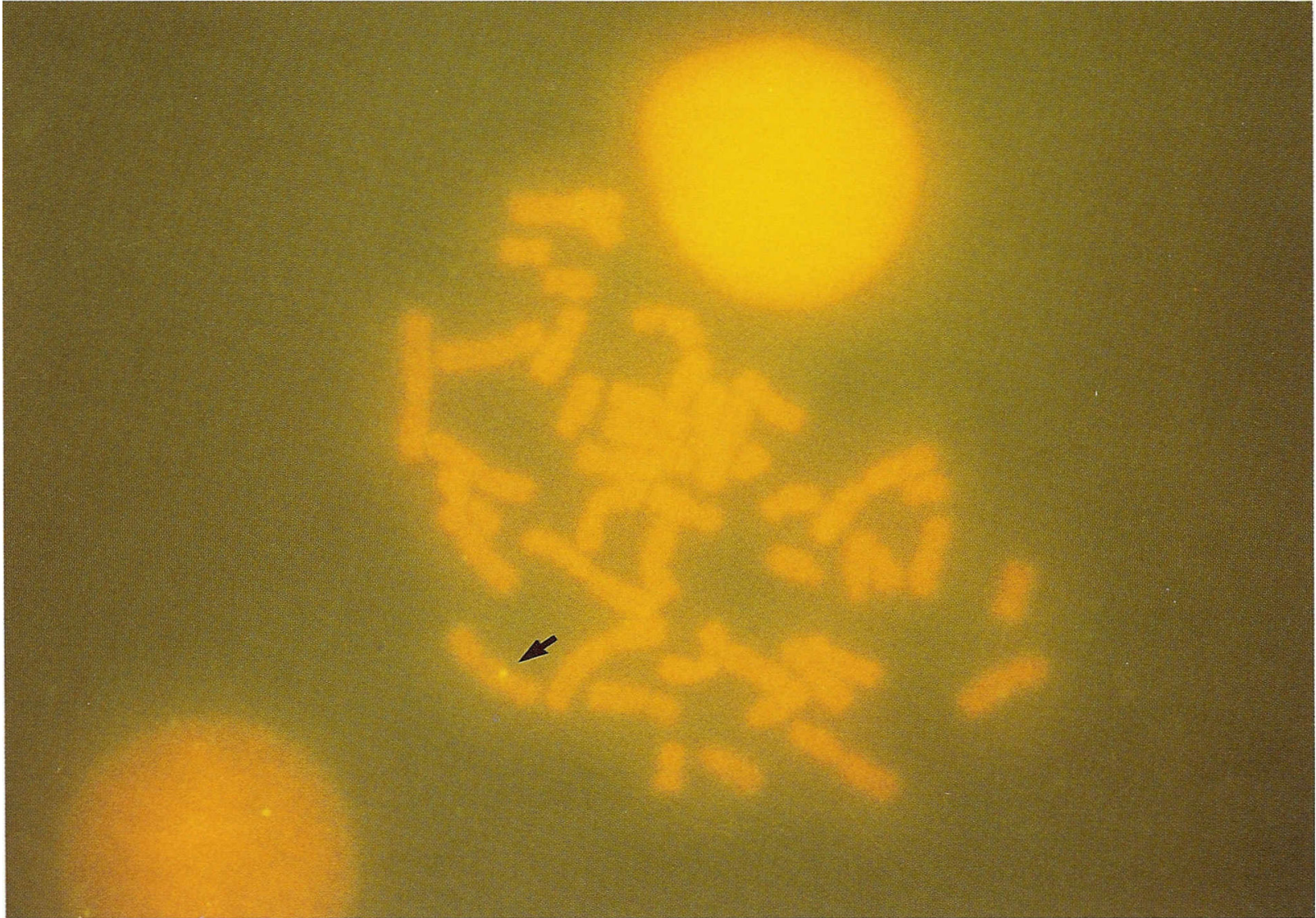

Fig. 3.

FISH. Hybridization is seen on chromosome $5 \mathrm{q} 13$. 